\title{
Risk Assessment of Heavy Metals Bioaccumulation in Clarias Gariepinus Tissues from Jakara Reservoir, Kano, Nigeria
}

${ }^{1}$ Rabiu, H. D., ${ }^{2}$ Abubakar, M. M. ${ }^{3}$ Mallam I

${ }^{1}$ Department of Biology, Federal College of Education (Technical)

Bichi, Kano State.

${ }^{2}$ Biological Sciences Department, Federal University, Dutse, Jigawa State

${ }^{3}$ Department of Environmental Management and Toxicology, Federal University Dutse, Jigawa State, Nigeria

Email: dhrabiu@gmail.com

\begin{abstract}
The risk of heavy metals bioaccumulation in gills and liver of C. gariepinus of Jakara Reservoir, Kano was assessed for period of twelve months (March, 2020 to February, 2021). In situ and in vitro examinations were performed using standard procedures. Sites for sampling were categorized into three as offshore (A), midshore (B) and inshore (C) were chosen based on the impact of varying humans activities within the reservoir. The mean range of physicochemical parameters were water temperature $\left(27.1-28.30^{\circ} \mathrm{C}\right)$, Dissolved Oxygen $(5.9-6.6 \mathrm{mg} / \mathrm{L})$, Biological Oxygen Demand $(2.4$ $3.7 \mathrm{mg} / \mathrm{L})$, transparency $(0.9-1.2 \mathrm{~m})$, electrical conductivity $(637.1-1064 \mu \mathrm{S} / \mathrm{cm}), \mathrm{pH}(7.8-8.1)$, and Total Dissolved Solids (433.1-733.8mg/L). Gills had accumulation of $\mathrm{Fe}, \mathrm{Cr}, \mathrm{Cu}, \mathrm{Pb}$ and $\mathrm{Cd}$ in a concentration graded fashion with $\mathrm{Fe}$ being the highest and $\mathrm{Cd}$ the lowest in terms of concentration. $B A F$ in liver tissues recorded a decrease in the following sequence: $\mathrm{Cu}>\mathrm{Cr}>\mathrm{Pb}>\mathrm{Fe}>\mathrm{Cd}$. Physicochemical parameters, heavy metals bioaccumulation differed significantly $(P<0.05)$ between the sites and seasons with the exception of TDS, EC, turbidity and Cadmium. It can be deduced that fluctuation in water quality parameters and heavy metals concentrations in the reservoir could be attributed to high influx of nutrients due to farming activities among other anthropogenic input. It is hereby recommended that indiscriminate discharge of agro chemicals among other domestic inputs should be minimized in order to curtail degradation of the reservoir in the long run. Relevant authorities should develop strategies to control potential effect of the pollutants on the aquatic biota in the water body.
\end{abstract}

Keywords: Bioaccumulation, Clarias gariepinus, Heavy metals, Jakara Reservoir, Physicochemical parameters, Pollution

\section{INTRODUCTION}

The availability of portable water is significant for wellbeing and preventing ailment that could pose danger to quality of life (Adamu et al., 2016). Aquatic ecosystem pollution is a 
worldwide problem requiring urgent attention (Dane and Sisman, 2017). Pollutants discharge into water bodies such as industrial, domestic and agricultural wastes results in various detrimental effects on the aquatic biota such as fish (Abubakar et al., 2012). Pollutants from these activities were reported to contain heavy metals such as $\mathrm{Cu}, \mathrm{Cr}$ and $\mathrm{Pb}$ which invariably, affects the entire aquatic ecosystem (Habu et al., 2021). Due to their toxic nature, non-biodegradable and accumulative potential, heavy metals constitute a core group of aquatic pollutants (Jamila and Sule, 2020). Heavy metals remain in soil particles and /or suspended in aquatic environment might be taken up by cells/tissues upon their entry into various system (Ahmad et al., 2018). In fish for instance, metals get absorbed through gills or assimilated via food to cause damage in biota whose intensity is attributed to temperature changes, dissolve oxygen and electrical conductivity of the aquatic environment (Ibrahim and Sa'id, 2010). The accelerated population growth, economic development and industrialization of Kano metropolis subject the application of untreated water to cater for the ever increasing population of the state (Muhammed et al., 2017). Monitoring and assessment of heavy metals concentrations in water bodies are required to evaluate the potential ecological risk of the water due to toxic heavy metals accumulation (Suleiman et al., 2020). Aquatic organisms such as fish retain pollutants higher than the quantity in the aquatic environment and sediments (Shawai et al., 2018). Fish are sentinel aquatic biota that are considered among the common organisms in used in environmental status biomonitoring. They are used in ecological/pollution status research because of their welldeveloped osmoregulatory, endocrine, nervous, and immune systems (Ahmad et al., 2018). In view of the above, this research investigates the heavy metals concentrations and bioaccumulation factor in tissues of C. gariepinus from Jakara Reservoir, Kano.

\section{MATERIALS AND METHODS}

\section{Study Area}

The study was carried out at Jakara reservoir (Figure 1), which was built in 1976. The main tributaries of the reservoir are River Jakara and River Getsi which collects most of Kano city's domestic and industrial waste water (Imam, 2012). Jakara reservoir is located within Sudan savannah zone between longitude $8^{\circ} 31^{\prime}$ to $8^{\circ} 45^{\prime} \mathrm{E}$ and latitude $20^{\circ} 13^{\prime}$ to $12^{\circ} 10^{\prime} \mathrm{N}$ in

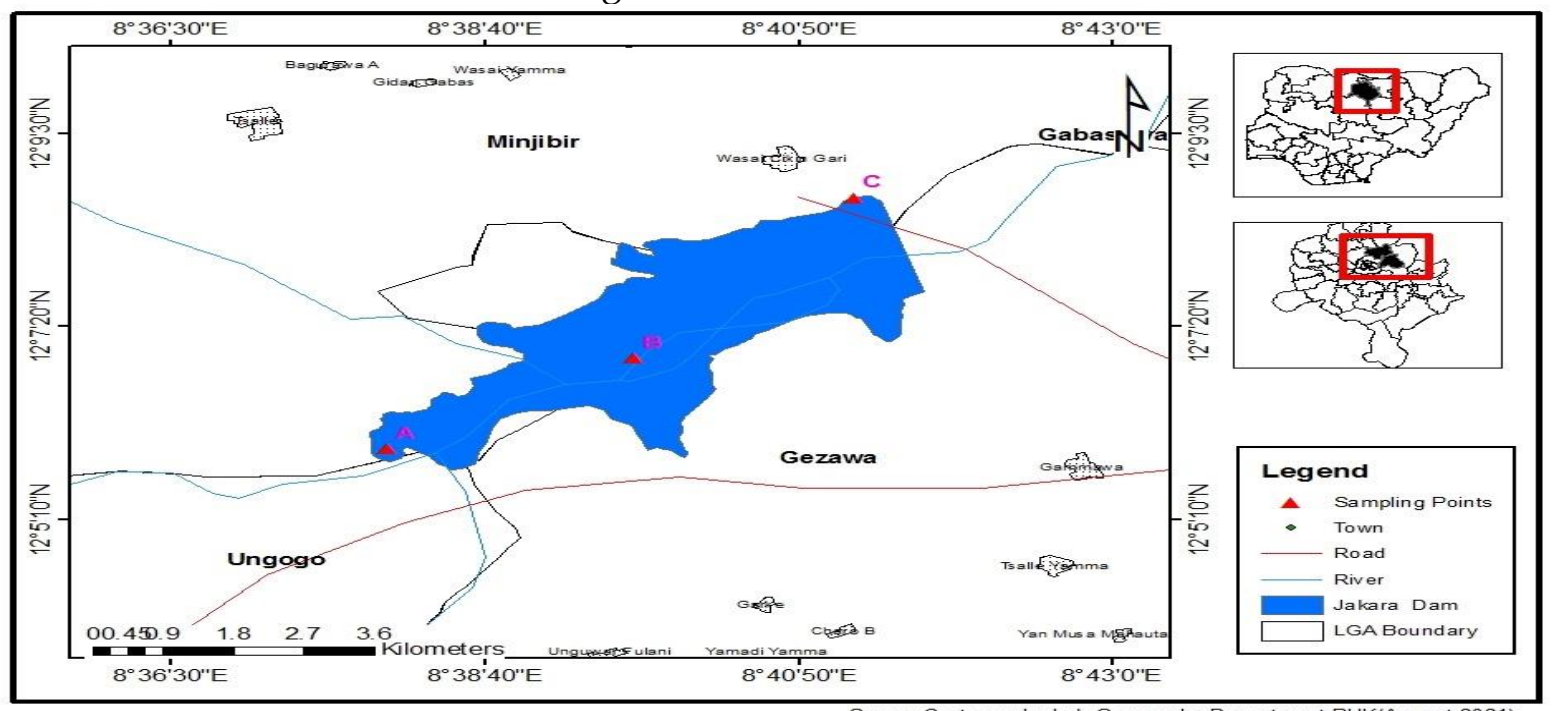

Fig1. Map of Jakara Reservoir Indicating the Sampling Sites (Source: Cartography Lab. Geography Dept. Bayero Univesity Kano, 2021) 
Wasai, a town in Minjibir local government area of Kano State, $41.5 \mathrm{~km}$ from Kano Metropolis. Two distinct seasons are experienced annually (wet and dry seasons) consisting of a long summer and short winter with annual mean temperature of $31^{\circ} \mathrm{C}$. The metrological data nearest to the area indicates an estimated average rainfall as $412 \mathrm{~mm}$ during months of July and August. The rainy season period lasts from May to September and dry season runs from October to April The water body contains muddy substratum and gently flowing, highly turbid with rich algal growth and macrophytes Sandy- loam and clay - loam are the soil types of the area of which they are rich in nutrients and other minerals (Badamasi, 2014). The communities around the reservoir depend basically on the water body as a source of livelihood by over-exploiting its abundant resources. They are largely fishers and farmers. Crops grown in this area which is estimated for about 5000 hectares of active agricultural land: include beans, cassava, maize, millet, rice, okra, onion, pumpkin and sorghum (Magaji and Rabiu, 2020). However, the wetland surrounding the reservoir serve as roosting and foraging area for many resident and migratory bird species (Magaji and Rabiu, 2020).

\section{Water Sampling}

Collection of water from the three sampling sites was on monthly basis for period of twelve months. Water sample was collected monthly between 7:00am to 7:30am from the three sampling sites. The choice of the sampling sites was based on the morphometric and impact of anthropogenic activities around the reservoir. Site A (inshore), Site B (midshore) and Site $\mathrm{C}$ (offshore) on the watercourse of the reservoir with $300 \mathrm{~m}$ distance apart between the sampling sites.

Site A: Site is close to Dinga village where Kano city major part of the waste water flow directly to this point from Dinga village. Irrigation activities take place during dry season and vegetation are subjected to chemicals input from agrochemical inputs at this site.

Site B: This site is the mid shore of the reservoir where there are less human activities apart from fishing.

Site C: Human activities such as recreation at Minjibir Park, laundry services, irrigation among other anthropogenic activities are carried out at this site.

\section{Physicochemical Parameters Analysis}

Water quality parameters were determined using multifunction water testing kit (Model no. EZ-9909-SP). Parameters such as water temperature, Dissolved oxygen, Biological oxygen demand Total Dissolved Solids, Electrical Conductivity, turbidity, $\mathrm{pH}$, Nitrate and Phosphate were determined according to the manufacturer's instruction.

\section{Heavy metals Determination in Fish Samples}

Fish samples (Clarias gariepinus) were achieved with aid of fish gears at the sites as described by Badamasi (2014). Fish captured were ice blocked and conveyed to the laboratory for digestion and heavy metals analysis. They were enumerated, weighted to the nearest $0.1 \mathrm{~g}$ using weighing balance (M-Metlar Model). The total lengths were assessed to the nearest $0.1 \mathrm{~cm}$ on a measuring board. The vital biometric features were examined on the fish species using identification key by Olaosebikan and Raji (1998).

The fish samples were dissected using the procedure adopted by Ahmad et al. (2018). Gills and liver were removed and oven dried at temperature of $105^{\circ} \mathrm{C}$ until it reached a constant 
weight. Each organ was grinded into powdery form and kept in the desiccator prior to digestion. The powdered samples were homogenized and subjected to digestion using concentrated nitric acid and hydrogen peroxide (1:1) v/v as adopted by Samson (2015). Exactly $2 \mathrm{~g}$ of the powder samples were weigh into a $250 \mathrm{ml}$ round bottom flask and $10 \mathrm{ml}$ each of $\mathrm{HNO}_{3}$ and $\mathrm{H}_{2} \mathrm{O}_{2}$ were added and the content of the flask was allowed to undergo digestion. The content of the flask was heated on a heating mantle to a temperature of $130^{\circ} \mathrm{C}$ till dissolution inside a fume hood to reduce the volume to $4 \mathrm{ml}$. The digested samples was allowed to cool and filtered into conical flask, the filtered sample was transferred to a $50 \mathrm{ml}$ volumetric flask and de-ionized water was used to further dilute the sample to $50 \mathrm{ml}$ in the volumetric flask. Heavy metals concentrations were determined using microwave plasma atomic spectroscopy (MP-AES) at center for dry land Agriculture (CDA), Bayero University, Kano.

\section{Bio-Accumulation Factor (BAF)}

Bioaccumulation factor (BAF) was calculated using the protocol described by Vaseem and Banerjee, 2013:

$\mathrm{BAF}=\mathrm{Cf} / \mathrm{Cw}$

where, $\mathrm{Cf}$ is concentration of metal in fish tissue $(\mathrm{mg} / \mathrm{Kg})$ and $\mathrm{Cw}$ is metal concentration in reservoir water $(\mathrm{mg} / \mathrm{L})$.

$\mathrm{MPI}=(\mathrm{Cf} 1 \times \mathrm{Cf} 2 \times \mathrm{Cf} 3 \times \ldots \mathrm{Cfn}) 1 / \mathrm{n}$

where $\mathrm{Cfn}$ is concentration of metal $\mathrm{n}$ in the given sample

$\mathrm{BAF}=\mathrm{M}$ tissue $/ \mathrm{M}$ water. Where; $\mathrm{M}$ tissue is the metal concentration in fish tissue $\mathrm{mg} / \mathrm{kg}$ and $\mathrm{M}$ water, metal concentration in water $\mathrm{mg} / \mathrm{L}$.

\section{Statistical Analyses}

Data were analyzed using R-Statistical software version 4.05 developed by Agricolae package (Dytham, 2011). The data was subjected to one way analysis of variance (ANOVA) to determine differences between sites and where differences exist they were separated with Duncan multiple range test (DMRT) at $0.05 \%$. Seasonal variations were analyzed using student's independent T-test. Pearson correlation was used to determine the degree of association between heavy metals and physicochemical parameters.

\section{RESULTS}

Spatial variation of physicochemical parameters recorded from Jakara Reservoir is presented in Table 1. The mean values of water temperature had the highest of $28.30 \pm 0.41{ }^{\circ} \mathrm{C}$ at site $\mathrm{B}$ while site $C$ had the lowest value of $27.1 \pm 0.04^{\circ} \mathrm{C}$. Spatially, significant difference $(\mathrm{P}<0.05)$ in water temperature was recorded between the sites. DO spatial variation was highest $(6.60 \pm 0.10 \mathrm{mg} / \mathrm{L})$ at site A while site B had the lowest value of $5.9 \pm 0.12 \mathrm{mg} / \mathrm{L}$. statistically no significant difference $(\mathrm{p}>0.05)$ in DO values between the sites. BOD site variation had higher value of $3.70 \pm 1.00 \mathrm{mg} / \mathrm{L}$ at site $C$ while the lowest value of $2.4 \pm 0.21 \mathrm{mg} / \mathrm{L}$ was obtained at site A which did not differ significantly $(\mathrm{p}>0.05)$ (Table1). Spatial variation of transparency showed that site B had the highest value of $1.2 \pm 0.1 \mathrm{mg} / / \mathrm{L}$ while site A recoded the lowest of $0.9 \pm 0.01 \mathrm{NTU}$. Transparency between sites did not differ significantly ( $\mathrm{p}>0.05)$ (Table 1). Electrical Conductivity had the highest mean value of $1064 \pm 0.16 \mu \mathrm{S} / \mathrm{cm}$ at site A while site $C$ recorded the lowest $637.1 \pm 0.14 \mu \mathrm{S} / \mathrm{cm}$. Spatially, there is no significant difference $(\mathrm{P}>0.05)$ in $\mathrm{EC}$ between the sites. During the study $\mathrm{pH}$ recorded ranged between $7.80 \pm 0.11-8.10 \pm 0.01$ at site $\mathrm{A}$ and $\mathrm{C}$ respectively. The $\mathrm{pH}$ value differed significantly between the sites $(\mathrm{p}<0.05)$. Mean spatial values of TDS ranged between $433.1 \pm 1.40 \mathrm{mg} / \mathrm{L}$ to $733.8 \pm 1.40$ $\mathrm{mg} / \mathrm{L}$ at site $\mathrm{C}$ and $\mathrm{A}$ respectively. Mean TDS values showed no significant difference between the sites $(\mathrm{P}>0.05)$. Spatial variation of phosphate-phosphorus concentration 
revealed that site $B$ had the highest value of $3.11 \pm 0.01 \mathrm{mg} / \mathrm{L}$ while site $A$ had the lowest value of $2.12 \pm 0.10 \mathrm{mg} / \mathrm{L}$. phosphate-phosphorus concentration between sites differed significantly $(\mathrm{p}<0.05)$ (Table1.). Nitrate-nitrite concentrations had the highest mean value of $7.01 \pm 0.11 \mathrm{mg} / \mathrm{L}$ at site $\mathrm{B}$ while $5.00 \pm 0.10 \mathrm{mg} / \mathrm{L}$ recorded at site C. Mean Nitrate-nitrite concentrations differed significantly between the sites $(\mathrm{P}<0.05)$.

Table 1: Spatial Variation of Physicochemical parameters obtained from Jakara Reservoir, Kano State

\begin{tabular}{|c|c|c|c|c|}
\hline Sampling Sites & $\mathbf{A}$ & B & $\mathrm{C}$ & FAO/WHO (2018) \\
\hline Water temperature $\left({ }^{\circ} \mathrm{C}\right)$ & $27.8 \pm \pm 0.16^{\mathrm{a}}$ & $28.3 \pm 0.41^{a}$ & $27.1 \pm 0.04^{b}$ & $<40^{\circ} \mathrm{Cmg} / \mathrm{L}$ \\
\hline $\mathrm{DO}(\mathrm{mg} / \mathrm{L})$ & $6.6 \pm 0.10^{\mathrm{a}}$ & $5.9 \pm 0.12^{\mathrm{a}}$ & $5.9 \pm 0.16^{b}$ & $5.0-9.0 \mathrm{mg} / \mathrm{L}$ \\
\hline $\mathrm{BOD}(\mathrm{mg} / \mathrm{L})$ & $2.4 \pm 0.21^{\mathrm{a}}$ & $2.9 \pm 0.01^{b}$ & $3.7 \pm 1.00^{\mathrm{a}}$ & $3.0-6.0 \mathrm{mg} / \mathrm{L}$ \\
\hline TDS (mg/L) & $733.8 \pm 1.40^{\mathrm{a}}$ & $529.1 \pm 0.66^{\mathrm{b}}$ & $433.1 \pm 0.10^{\mathrm{a}}$ & $<500 \mathrm{mg} / \mathrm{L}$ \\
\hline $\begin{array}{l}\text { ElectricalConductivity } \\
(\mu \mathrm{S} / \mathrm{cm})\end{array}$ & $1064 \pm 0.16^{a}$ & $875.3 \pm 1.61^{\mathrm{b}}$ & $637.1 \pm 0.14^{\mathrm{a}}$ & $<1000 \mu / \mathrm{Scm}$ \\
\hline Transparency (m) & $0.9 \pm 0.001^{\mathrm{a}}$ & $1.2 \pm 0.11^{\mathrm{a}}$ & $0.9 \pm 0.03^{b}$ & $<25 \mathrm{NTU}$ \\
\hline $\mathrm{pH}$ & $7.8 \pm 0.11^{\mathrm{a}}$ & $7.9 \pm 0.10^{b}$ & $8.1 \pm 0.01^{\mathrm{a}}$ & $6.0-9.0$ \\
\hline $\begin{array}{l}\text { Phosphate - phosphorus } \\
(\mathrm{mg} / \mathrm{L})\end{array}$ & $2.12 \pm 0.10^{\mathrm{b}}$ & $3.11 \pm 0.01^{\mathrm{a}}$ & $2.28 \pm 0.11^{b}$ & $0.1 \mathrm{mg} / \mathrm{L}$ \\
\hline Nitrate - nitrites $(\mathrm{mg} / \mathrm{L})$ & $6.11 \pm 0.11^{\mathrm{a}}$ & $7.01 \pm 0.11^{\mathrm{a}}$ & $5.00 \pm 0.10^{\mathrm{b}}$ & $5 \mathrm{mg} / \mathrm{L}$ \\
\hline
\end{tabular}

Mean values with different superscript alphabet in a row differed significantly $(\mathrm{P}<0.05)$ Table 2 illustrates the spatial variation of $\mathrm{Cr}, \mathrm{Fe}, \mathrm{Cd}, \mathrm{Cu}$ and $\mathrm{Pb}$ concentrations in liver and gills of $\mathrm{C}$. gariepinus sampled from Jakara Reservoir. The $\mathrm{Pb}$ had the highest concentration $(0.14 \mathrm{mg} / \mathrm{L})$ in gills at site $\mathrm{C}$ compared with liver $(0.06 \mathrm{mg} / \mathrm{L})$ at sampling site $\mathrm{B}$. $\mathrm{Pb}$ concentrations didnt differ significantly between sites $(\mathrm{p}<0.05)$. $\mathrm{Cu}$ had the highest mean value in gills at sampling site A $(0.34 \mathrm{mg} / \mathrm{L})$, followed by site $B(0.03 \mathrm{mg} / \mathrm{l})$ in gills and lowest concentration recorded in liver at sampling site $C$ with $1.15 \mathrm{mg} / \mathrm{L}$ Spatially, significant difference in $\mathrm{Cu}$ was recorded between the sites $(\mathrm{P}<0.05)$. $\mathrm{Cr}$ concentrations had the highest value in gills at sites $\mathrm{A}$ and $\mathrm{C}$ compared to $\mathrm{B}$ respectively, but record the highest value of $1.03 \mathrm{mg} / \mathrm{L}$ at site $\mathrm{B}$ in the liver. The $\mathrm{Cr}$ concentrations did not differ significantly between the sites $(\mathrm{p}>0.05)$. Mean Cd concentration spatially was highest in gills at site B 0.10 $\mathrm{mg} / \mathrm{L}$ than in the liver from site $\mathrm{A}$ and $\mathrm{B}$ respectively. Mean $\mathrm{Cd}$ concentration revealed significant difference between the sampling sites $(\mathrm{P}<0.05)$. Fe had the highest mean value in liver at sampling site A $6.03 \mathrm{mg} / \mathrm{L}$ followed by site B with $4.01 \mathrm{mg} / \mathrm{L}$ and lowest concentration recorded in gills at site B. Spatially, significant difference in Fe was recorded between the sites $(\mathrm{P}<0.05)$. 
Table 2: Spatial Variation of Heavy Metal concentrations in fish tissues of $C$. gariepinus Obtained from Jakara Reservoir, Kano, Nigeria

\begin{tabular}{|c|c|c|c|c|c|c|}
\hline \multicolumn{2}{|c|}{$\begin{array}{l}\text { Parameters/tissues } \\
(\mathrm{mg} / \mathrm{g})\end{array}$} & \multirow{2}{*}{$\begin{array}{l}\text { Site A } \\
0.02 \pm 0.10^{\mathrm{a}}\end{array}$} & \multirow{2}{*}{$\begin{array}{l}\text { Site B } \\
1.03 \pm 1.01^{\mathrm{a}}\end{array}$} & \multirow{2}{*}{$\begin{array}{l}\text { Site C } \\
0.01 \pm 0.01^{\mathrm{a}}\end{array}$} & \multirow{2}{*}{$\begin{array}{l}\text { BAF } \\
0.16\end{array}$} & \multirow{2}{*}{$\begin{array}{l}\begin{array}{l}\text { FAO/WHO } \\
(\mathbf{2 0 1 8})\end{array} \\
0.05\end{array}$} \\
\hline Cr (mg/kg) & Liver & & & & & \\
\hline & gills & $0.59 \pm 0.01^{\mathrm{a}}$ & $0.01 \pm 0.00^{\mathrm{a}}$ & $0.10 \pm 0.00^{\mathrm{bc}}$ & 0.06 & \\
\hline \multirow[t]{2}{*}{$\mathrm{Cu}(\mathrm{mg} / \mathrm{kg})$} & Liver & $1.37 \pm 0.01^{\mathrm{ab}}$ & $1.95 \pm 0.01^{b c}$ & $1.15 \pm 0.06^{\mathrm{a}}$ & 0.64 & 2.0 \\
\hline & gills & $0.34 \pm 0.01^{a}$ & $0.03 \pm 0.01^{a}$ & $0.01 \pm 0.00^{\mathrm{ac}}$ & 0.06 & \\
\hline \multirow[t]{2}{*}{$\mathrm{Pb}(\mathrm{mg} / \mathrm{kg})$} & Liver & $0.12 \pm 0.02^{\mathrm{ac}}$ & $0.06 \pm 0.01^{\mathrm{a}}$ & $0.01 \pm 0.012^{\mathrm{a}}$ & 0.03 & 0.05 \\
\hline & gills & $0.10 \pm 0.10^{\mathrm{a}}$ & $0.01 \pm 0.01^{a}$ & $0.14 \pm 0.01^{\mathrm{a}}$ & 0.06 & \\
\hline \multirow[t]{2}{*}{$\mathrm{Cd}(\mathrm{mg} / \mathrm{kg})$} & Liver & $0.01 \pm 0.01^{\mathrm{a}}$ & $0.01 \pm 0.00^{\mathrm{ab}}$ & $0.01 \pm 0.01^{\mathrm{a}}$ & 0.01 & 0.05 \\
\hline & gills & $0.01 \pm 0.01^{\mathrm{a}}$ & $0.10 \pm 0.001^{a}$ & $0.01 \pm 0.01^{\mathrm{a}}$ & 0.001 & \\
\hline \multirow[t]{2}{*}{$\mathrm{Fe}(\mathrm{mg} / \mathrm{Kg})$} & Liver & $6.03 \pm 0.01^{\mathrm{a}}$ & $4.01 \pm 0.00^{\mathrm{ab}}$ & $4.71 \pm 0.01^{\mathrm{a}}$ & 0.01 & 5.00 \\
\hline & gills & $2.10 \pm 0.01^{\mathrm{a}}$ & $1.01 \pm 0.001^{\mathrm{a}}$ & $2.10 \pm 0.01^{\mathrm{a}}$ & 0.001 & \\
\hline
\end{tabular}

Mean values with different superscript alphabet in a row differed significantly $(\mathrm{P}<0.05)$ Monthly variation of heavy metals concentrations in fish tissues recorded from Jakara Reservoir is presented in Fig. 2. The mean monthly concentrations of $\mathrm{Pb}$ from gills tissue was highest $(1.25 \pm 1.01 \mathrm{mg} / \mathrm{L})$ in September while the lowest concentration of $0.28 \pm$ $0.11 \mathrm{mg} / \mathrm{L}$ was obtained December from liver tissues. Lead $(\mathrm{Pb})$ concentrations revealed significant difference in months $(\mathrm{p}<0.05)$. Monthly variation revealed significant difference $(\mathrm{p}<0.05)$ for $\mathrm{Cu}$ in gills tissues during the study period (July - December) while liver tissue showed no significant difference $(\mathrm{p}>0.05)$. Mean monthly values for $\mathrm{Cr}$ in gills ranged between $0.34 \pm 0.04 \mathrm{mg} / \mathrm{L}$ in December to $1.73 \pm 0.02 \mathrm{mg} / \mathrm{L}$ in August. The Cr concentration in liver ranged between $0.21 \pm 0.21 \mathrm{mg} / \mathrm{L}$ to $0.88 \pm 0.01 \mathrm{mg} / \mathrm{L}$ in December and October respectively. Mean monthly concentrations of $\mathrm{Cr}$ differed significantly $(p>0.05)$. Fe concentrations revealed significant monthly difference $(p<0.05)$.

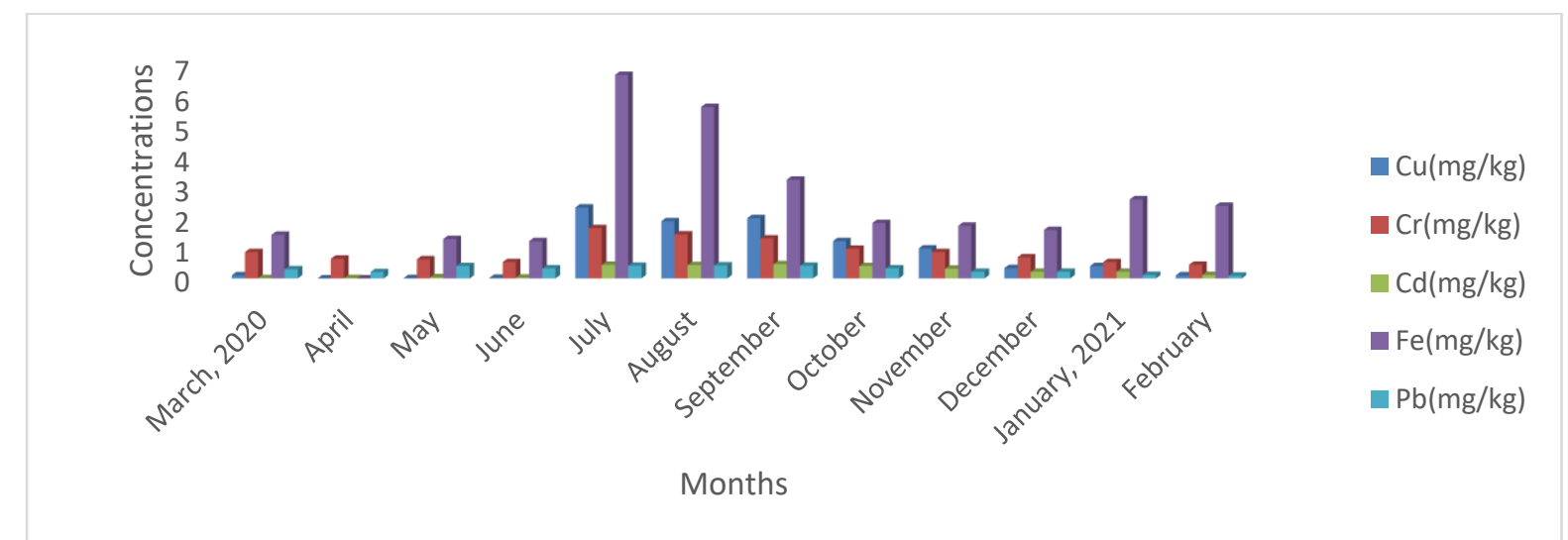

Fig 2: Monthly variation of Heavy metal Concentrations in Fish Tissues obtained from Jakara reservoir, Kano State 
Mean concentration of $\mathrm{Cu}$ during wet season was highest in the gills $0.99 \mathrm{mg} / \mathrm{kg}$ compared with liver $0.43 \mathrm{mg} / \mathrm{kg}$ (Table 3). Cu concentration differed between seasons and indicated no significant difference $(\mathrm{p}>0.05)$. Seasonally, the highest mean $\mathrm{Cr}$ concentration in Gills was obtained during wet season while lowest value was recorded in dry season. Seasonal variation of $\mathrm{Cr}$ didn't differ significantly between seasons $(\mathrm{P}>0.05)$ in all the fish parts. The seasonal variations in the mean $\mathrm{Cd}$ concentrations indicated that dry season had 0.018 $\mathrm{mg} / \mathrm{kg}$ while wet season recorded highest value of $0.394 \mathrm{mg} / \mathrm{kg}$ in gills. No significant difference $(p>0.05)$ in $C d$ concentration between the seasons $(p>0.05)$. The mean seasonal variation of $\mathrm{Pb}$ showed that wet season had $0.705 \mathrm{mg} / \mathrm{kg}$ in gills while $0.320 \mathrm{mg} / \mathrm{kg}$ was recorded during dry season, and $0.031 \mathrm{mg} / \mathrm{kg}$ in wet season and 0.011 in dry season in the liver. Statistically, $\mathrm{Pb}$ revealed no significant difference between the two seasons ( $\mathrm{p}>0.05)$. Seasonally highest mean value of Fe concentration in liver was obtain in wet season 3.75 $\mathrm{mg} / \mathrm{kg}$ and in gills $3.35 \mathrm{mg} / \mathrm{kg}$, the lowest value was obtain in dry season in kidney 1.013 $\mathrm{mg} / \mathrm{L}$. Statistically there was significant difference between the two seasons $(\mathrm{p}<0.05)$.

Table 3: Seasonal Variation of Mean Heavy Metals Concentrations in Different Parts of C. gariepinus in Jakara Reservoir

Parts Season Heavy metals

$\mathrm{Cr}(\mathrm{mg} / \mathrm{kg}) \quad \mathrm{Cd}(\mathrm{mg} / \mathrm{kg}) \quad \mathrm{Cu}(\mathrm{mg} / \mathrm{kg}) \quad \mathrm{Fe}(\mathrm{mg} / \mathrm{kg}) \quad \mathrm{Pb}(\mathrm{mg} / \mathrm{kg})$

\begin{tabular}{|c|c|c|c|c|c|c|}
\hline Liver & $\begin{array}{l}\text { Dry } \\
\text { Wet }\end{array}$ & $\begin{array}{l}0.850^{\mathrm{a}} \\
0.780^{\mathrm{b}}\end{array}$ & $\begin{array}{l}0.010^{\mathrm{a}} \\
0.021^{\mathrm{a}}\end{array}$ & $\begin{array}{l}0.43^{\mathrm{a}} \\
0.64^{\mathrm{a}}\end{array}$ & $\begin{array}{l}2.370^{\mathrm{a}} \\
3.745^{\mathrm{b}}\end{array}$ & $\begin{array}{l}0.011^{\mathrm{a}} \\
0.031^{\mathrm{a}}\end{array}$ \\
\hline Gills & $\begin{array}{l}\text { Dry } \\
\text { Wet }\end{array}$ & $\begin{array}{l}0.224^{\mathrm{a}} \\
0.574^{\mathrm{a}}\end{array}$ & $\begin{array}{l}0.018^{\mathrm{a}} \\
0.394^{\mathrm{a}}\end{array}$ & $\begin{array}{l}0.834^{\mathrm{a}} \\
0.990^{\mathrm{a}}\end{array}$ & $\begin{array}{l}2.569^{\mathrm{a}} \\
3.350^{\mathrm{b}}\end{array}$ & $\begin{array}{l}0.320^{\mathrm{a}} \\
0.705^{\mathrm{a}}\end{array}$ \\
\hline
\end{tabular}

Means followed by superscript with different letters across the column are significant at $\mathrm{P}<0.05$ using T. test

\section{DISCUSSION}

\section{Physicochemical Parameters in Water}

Physicochemical parameters are indispensable ecological factors regulating the physiological indices and distribution of aquatic organisms (Arimoro et al., 2018). Water temperature affects chemical reactions in aquatic organisms and solubility of gases (Rabiu et al., 2018). During the study period, water temperature recorded from Jakara Reservoir differed seasonally without any significant difference among the three sampling sites. Similar range of temperature variation of $22-27.8^{\circ} \mathrm{C}$ was reported by Ibrahim and Nafiu (2017) in Watari Dam, Kano State. The monthly variations in water temperature observed is attributed to the rainfall regime in this ecological zone by being a significant factor affecting aquatic biota pattern in tropical water bodies as reported by Arimoro et al. (2018). The relatively high water temperature recorded in July could be characteristically due to hot weather in the Northern part of Nigeria. Similar pattern of temperature changes is in consistent with the observation reported by Ibrahim and Nafiu (2017) and Rabiu et al. (2018) in Thomas Dam and Watari Reservoir respectively. The lowest ambient water temperature were observed in the December which is attributed to the characteristic cool dry North-East trade wind (Harmattan). This pattern of variation temperature has been reported in Northern Nigeria by Akindele et al. (2013) in Tiga Lake, Kano. 
Hydrogen ion concentration $(\mathrm{pH})$ maintains the mobility, solubility and availability of ions in water bodies (Reddy, 2018). The $\mathrm{pH}$ range of 6.0 to 9.0 provide protection for life of fresh water fish and other bottom dwelling biota (FAO/WHO, 2018). Spatial and temporal $\mathrm{pH}$ value recorded ranged from 7.6-8.3, indicates that the water body is favourable to support aquatic life. The mean $\mathrm{pH}$ obtained throughout the study period in Jakara reservoir made the water to be circum-neutral which is in harmony with the findings of Usman and Adakole, (2017) in Ajiwa reservoir who reported water $\mathrm{pH}$ for aquatic life in the range of $6.67 \pm 0.08$ to $7.34 \pm 0.12$. Similarly, the mean $\mathrm{pH}$ value spatially were within the acceptable limit of 6.5-8.5 recommended for surface fresh water bodies (FAO/WHO, 2018). The high $\mathrm{pH}$ value recorded at sites $\mathrm{C}$ could be due to anthropogenic activities while the low $\mathrm{pH}$ value at Site $\mathrm{A}$ could be due to agricultural runoffs with varying $\mathrm{pH}$ conditions into the reservoir. Temporal variation revealed high $\mathrm{pH}$ values in dry season than in wet season. The high $\mathrm{pH}$ value obtained could be due to the high concentrations of dissolved ions in water and input for agrochemicals causing an increase in the water $\mathrm{pH}$. This corroborates with findings of Adamu et al. (2016) and Rabiu et al. (2018) who reported an increase in pH values during the dry season in Watari reservoir, Kano.

Electrical conductivity is a signal to the total ionic composition in aquatic environment. The electrical conductivity recorded within the sampling sites agrees with that of freshwater body of $1-1000 \mathrm{uS} / \mathrm{cm}$ set by FAO/WHO (2018) with exception of sampling site C where $1301.21 \pm 0.19 \mu \mathrm{s} / \mathrm{cm}$ above the permissible limit was recorded. The higher mean conductivity obtained at site $C$ is an indication of the presence of more ions influx into the site via anthropogenic activities such as agrochemicals among other inorganic materials from the surroundings stream. Similar observation of high EC spatially was reported by Rabiu et al. (2018) in Watari Reservoir. Monthly variation for electrical conductivity revealed that July had the highest value of $1098.67 \pm 1.01 \mu \mathrm{s} / \mathrm{cm}$ while the lowest of $415.33 \pm 1.09$ was obtained in December. The highest value in July corresponds with onset of rainy season where an increase in nutrient load as a result of indiscriminate discharge of agrochemicals from nearby farmlands takes place. Similar observation was reported by Adamu et al. (2016) in Thomas reservoir, Kano who depicted that fluctuation of electrical conductivity is due to variation in the rate of decomposition of organic matter, inflow of nutrients from agricultural runoff and presence of inorganic salt. Seasonal variation indicated an increased in electrical conductivity in dry season (October-December) than wet season (July September). The increase in mean values in dry season could be due to decreased in the water level and high runoff input from irrigation activities from nearby farmland as reported by Usman et al. (2017) in Ajiwa reservoir and Ibrahim and Nafiu (2017) in Thomas Dam, Kano.

Total Dissolved Solid (TDS) spatially indicated high value at sampling site C of $658 \pm 2.40$ $\mathrm{mg} / \mathrm{L}$ while site A had the least of $356 \pm 1.27 \mathrm{mg} / \mathrm{L}$. The high values at site $\mathrm{C}$ could be attributed to high inorganic salts and dissolved materials from nearby domestic input. The TDS values recorded is above the maximum limit of $600 \mathrm{mg} / \mathrm{L}$ set by FEPA (1991) for fresh water bodies. Temporal variation revealed highest TDS in dry season higher than in wet season. The high value obtained might be due to vegetation decompostion and wind effect, causing to an increase in the total dissolved ions. This is in tandem with findings of Rabiu et al. (2018) who obtained higher total dissolved ions during the dry season relating it to dissolved materials and rise in amount of dissolved solids. Similar observation in high TDS was also reported by Abubakar and Abdullahi (2015) in Jakara Dam, Kano. 
Turbidity in Jakara Reservoir varied significantly between the sampling sites and it did not indicate any significant difference among the sampling sites. High turbidity at site $\mathrm{C}$ might be attributed to the light transmission decline through the water to benthic aquatic fauna which affect the rate of photosynthesis as well. Similar sites variation in turbidity is reported by Imam and Balarabe (2012) in Jakara water body, Kano. Seasonal variation indicated higher value turbidity values in dry season than wet season. Higher mean values in dry season might be as a result of the decrease in the water level and wind action which facilitates agrochemical input from nearby farmland as reported by Akindele et al. (2013) in Tiga Dam and Abubakar and Yakasai (2015) in Hadejia-Nguru wetlands. The turbidity values recorded were higher than the permissible limit of 25NTU set by FAO/WHO (2018). Turbidity value obtained in this study is higher than what was reported from the same ecological zone by Ibrahim and Ibrahim (2017) in Jakara Reservoir who had a mean turbidity of 34.7NTU. Dissolved oxygen (DO) is one of the pronounced indices indicating water purity. Biological processes associated with decomposition causes a decline in DO concentrations (Umma et al., 2014). The value of Dissolved Oxygen recorded during the study period ranged between $4.57 \pm 0.12 \mathrm{mg} / \mathrm{L}$ and $5.67 \pm 0.11 \mathrm{mg} / \mathrm{L}$. DO value did not indicate any significant difference among the three sampling sites. Spatial variation in DO might be due to the exchange between atmospheric input, other physiological processes such as losses by biotic oxidations as obtained by Oladeji (2020) who reported DO value between 5.50 $6.30 \mathrm{mg} / \mathrm{L}$.

Temporal variation in DO revealed that dry had the mean value $5.96 \pm 0.69 \mathrm{mg} / \mathrm{L}$ compared to rainy season of $5.59 \pm 1.81 \mathrm{mg} / \mathrm{L}$. The high value of DO in dry season corresponds with hamattan period where a decrease in microbial activity happened due organic matter decomposition as reported by Imam and Balarabe (2012). The DO concentration in water alternates due to wind action, temperature variation and degradation activities (Rabiu et al. 2018). The cool harmattan wind have been reported to cause higher wind action and a decline in surface water temperature leading to an increased oxygen concentration during the dry season while the torrential rains led to a decline in oxygen concentration during wet season (Rabiu et al. 2018).

Biochemical Oxygen Demand (BOD) is the quantity of oxygen needed by microorganisms for stabilizing biologically decomposable organic compounds in water under aerobic conditions (Adamu et al., 2016). It had regarded as indispensable water quality indices for assessing pollution status in aquatic environment (Kutama et al., 2014). During the study period higher mean BOD was obtained at site $\mathrm{C}$ of $3.50 \pm 0.47 \mathrm{mg} / \mathrm{L}$ while the lowest of $2.22 \pm 0.05 \mathrm{mg} / \mathrm{L}$ was recorded at site A. Higher BOD recorded an indication of higher the decomposable matter present or due to the presence of detritus in the reservoir as reported by Ibrahim and Abdullahi (2017). Seasonal variation indicated higher mean BOD values in wet season than in the dry season (October-December). Higher mean BOD in wet season could be due to high decomposition and accumulated detritus coupled with high nutrient input from wind action and agrochemical input from nearby farms which led to DO reduction as reported by Ibrahim and Nafiu (2017) in Jakara Reservoir.

$\mathrm{Pb}$ had the highest concentration in gills at sampling sites $\mathrm{B}$ and $\mathrm{C}$ compared with liver. High concentrations of $\mathrm{Pb}$ in the gills might be due direct contact the gills with contaminated medium which led to their deposition and mobilization from gills as reported by Friday et al. (2013) from Owubu Creek, Nigeria. It could also be due to the large influx of runoff from domestic wastes discharged into the reservoir. Introduction of agrichemicals, leaded gasoline by vehicles, paints and cosmetics particles into the reservoir might also 
contributed in high $\mathrm{Pb}$ concentrations fish tissues under investigations. Similar observation for high value of $\mathrm{Pb}$ in fish tissues was reported by Imam and Balarabe (2012) and Samson etal. (2015) from Wasai and Tiga reservoirs respectively. The highest Pb value obtained of $0.91 \mathrm{mg} / \mathrm{kg}$ in gills tissues is in higher than $0.57+0.20 \mathrm{mg} / \mathrm{kg}$ reported by Ibrahim and Said (2010) in Jakara dam Kano. The concentrations of $\mathrm{Pb}$ recorded in the fish tissues (gills and liver) were above the recommended limit of $0.01 \mathrm{mg} / \mathrm{kg}$ set by FAO/WHO (2018) but lower than was obtained by Sobhan et al. (2011) in gill tissues.

$\mathrm{Cu}$ had the highest mean concentrations in gills at sampling site $\mathrm{C}$, followed by site $\mathrm{B}$ and least was recorded in liver tissues at sampling site $\mathrm{A}$. High value of $\mathrm{Cu}$ recorded in the gills could be due to the physiological role of the organ, its regulatory ability and feeding habit which play a vital role in bioaccumulation potentialities (Adewunmi et al., 2017) and Butu et al. (2019). The ionic nature of $\mathrm{Cu}$ and $\mathrm{pH}$ also tends to be another factor in the accumulation process (Samson, 2020). The $\mathrm{Cu}$ concentrations in all the tissues examined were below the recommended limit of $\mathrm{Cu} 2.0 \mu \mathrm{g} / \mathrm{g}$ set by FAO/W H O (2018). The values recorded were higher than $0.04 \mu \mathrm{g} / \mathrm{g}$ and $1.12 \mu \mathrm{g} / \mathrm{g}$ in gills and liver recorded by Ahmad et al. (2018) from Kafinchiri Reservoir, Kano.

Chromium in trace amount act as regulator of cholesterol metabolism but in higher value chromium is proof to be toxic to aquatic biota (Farombi et al., 2007). The current finding indicates the range of $\mathrm{Cr}$ between undetected in liver of $2.15 \mathrm{mg} / \mathrm{kg}$ in the gills. High concentration in gill tissues could be attributed to proximity with contaminated medium resulting to their deposition and mobilization than in the liver (Friday et al., 2013). Heavy metals concentrations in gills have been reported with the ionic exchange in the mucus memebrane, which making difficult to be detached completely between the lamellae; therefore high concentrations of various metals can be recovered (Adamu et al., 2016; Butu et al., 2018 and Samson et al., 2020). The Cr value obtained in this study is lower than 28.1 $32.2 \mathrm{mg} / \mathrm{Kg}$ in C. gariepinus's gills recorded by Ishaq et al. (2011) from Benue water body. But lower than $0.42 \pm 0.02-0.49 \pm 0.14 \mu \mathrm{g} / \mathrm{g}$ in gill tissues recorded by Dimari et al. (2008) from Alao Dam, Borno State. Cr recovered from the reservoir might have come from dying and tanning activities by the locals along the reservoir tributaries as reported by Shawai et al. (2018). The concentrations of $\mathrm{Cr}$ in gills and liver tissues in Clarias gariepinus might also be due to the predatory feeding habit of the examined fish, leading to metal enrichment at higher trophic levels as reported by Nsofor et al. (2014).

Cadmium in gills had its highest concentration in August which was higher than the recommended limit of $0.01 \mathrm{mg} / \mathrm{Kg}$ set by FAO/WHO (2018). Low value of Cd recorded in the fish tissues might have come from geological pattern in the study area and runoff from agrochemical input around the reservoir. Similar findings were reported by Putshaka et al. (2015) and Butu et al. (2019) from Challawa and Thomas reservoir, Kano respectively. Cd concentrations recovered might be due to contamination of fish by waste water containing phosphate pesticides and other domestic sewage which are regarded as prominent sources of Cd pollution in the water. Farombi et al. (2007) reported that waste water contaminated with $\mathrm{Cd}$ can results in anemia, vertebral fractures, and osmoregulatory problems. The Cd concentration examined in this study was lower than what was recorded by Farombi et al. (2007) and Ishaq et al. (2011) who obtained value of 0.69ppm and $0.927 \mathrm{ppm}$ in the gills of $C$. gariepinus from Ogun and Benue water body. Water contaminated with $\mathrm{Cd}$ has been reported to cause loss of membrane bound enzyme activity in fish tissue resulting in cellular death (Hosnia et al., 2015). 
Heavy metals have been reported as potent toxic compounds due to their slow degradation rate and non-biodegradable nature (Abdullahi et al., 2021). Variations in BAF rely on many conditions, such as age of the fish, physiology of the fish, migratory ability of fish, differential exposure and health conditions (Abdullahi et al., 2021; Habu et al., 2021). The BAF recorded is lower than 5.76 reported by Ahmad et al. (2018) in Kafinchiri reservoir, Kano State.

\section{CONCLUSION AND RECOMMENDATIONS}

The study showed alterations in heavy metals concentrations in the gills and liver of Clarias gariepinus from Jakara reservoir. This indicates that the sampled fish had high concentration of heavy metals contaminants via domestic input among other sources into the water body. Increasing concentration of the chemical contaminants affects the fish wellbeing. Consumption of this aquatic biota may pose risk to the inhabitants.

It is therefore recommended that proper water quality monitoring and anthropogenic activities in and around the reservoir should be enforced. Agricultural workers around the reservoir should be enlightened on the effect of their activities on the water quality, especially application of both organic and inorganic fertilizers and chemical pesticides during period of rainy season farming and irrigation activities. Monitoring of heavy metals in Jakara reservoir by the relevant authorities to ascertain the level of pollutants regularly is highly recommended. Effective waste disposal mechanism should be adopted to save the water and aquatic biota such as fish from contamination.

\section{REFERENCES}

Abalaka, E. A (2015). Heavy metals bioaccumulation and histopathological changes in Auchenoglanis occidentalis fish from Tiga dam, Nigeria. Journal of Environmental Health Science \& Engineering, 13(6):1-8.

Abdullahi N., Igwe E.C., and Dandago M.A. (2021). Heavy metals contamination through consumption of contaminated food crops. Moroccan Journal of Agricultural Sciences, 2: 52-60.

Abdullahi Y.A., and Mohammed M.A. (2020). Speciation, Bioavailability and Human Health Risk of Heavy Metals in Soil and Spinach (Amaranthus spp.) in Kano Metropolis, Northwestern-Nigeria. ChemSearch Journal, 11: 35-43.

Abubakar, A. and Abdullahi, B.A. (2015). Flora Composition of Phytoplankton as Bioindicators of Water Quality in Jakara Dam,Kano State,Nigeria.Bayero Journal of Pure and Applied Sciences, 8(2) 145-155.

Abubakar M.A., Dawaki M.U., and Ogbe V.B. (2020). Using Soil Depth Functions to Display Profile Organic Carbon Content along three Rivers in Nigeria. Agricultural Research Journal, 57:31.

Abubakar, M.M;., Balarabe M.L. and Auta, J. (2012). Effects of Physico-chemical Factors on Seasonal Dynamics of the Phytoplankton in Nguru Lake. Northeastern Nigeria. Journal of Natural sciences research,2(8):74-81.

Adamu, G. A., Sallau, M.S., Idris, S. O and Agbaji, E. B. (2016). Surface and Drinking Water Quality Monitoring of Thomas Reservoir, Kano State, Nigeria. International Journal of Chemical and Molecular Engineering, 10(12): 1439-1443. 
Adewunmi, A.A., Edward, J.B., Idowu, E.O., Oso J.A. and Apalowo A.O. (2017). Assessment of the heavy metals in some fish species of Elemi River, Ado-Ekiti, south west Nigeria. Agricultural Science Research Journal, 7(3): 103 - 110

Ahmad, H. K. and Indabawa, I. I. (2015). A Study of Algal Species of Kano River, Tamburawa, Kano State, Nigeria. Bayero Journal of Pure and Applied Sciences, 8(1): 42 49.

Ahmad, M.K., Nafiu, S. A., Baba, H. A., Rashida, I. U., Zakariyya, M and Abubakar, S. (2018). Heavy Metals Bioaccumulation In Tissues Of Indicators Of Water Pollution In Kafinchiri Reservoir, Kano, Nigeria. Bayero Journal of Pure and Applied Sciences, 11(1): 206-213.

Ahmed U.A., and Sadau M.A. (2015). Vegetable Crops of Peri-Urban Farms along Jakara River and Associated Insect Pests. Academic Conference of African Scholar Publications $\mathcal{E}$ Research International on Indiscipline Approaches, 6: 1-.6.

Akindele, E.0O., Adeniyi, I. F. and Indabawa, I. I. (2013). Spatio-Temporal Assessment and Water Quality Characteristics of Lake Tiga, Kano, Nigeria. Research Journal of Environmental and Earth Sciences, 5(2): 67-77.

Arimoro, F. O., Henry E. Olisa, Unique N. Keke, Adesola V. Ayanwale, Victoria I. Chukwuemeka. (2018). Exploring spatio-temporal patterns of plankton diversity and community structure as correlates to water quality in tropical stream. Acta Ecologica Sinica, 38 (1): 216-223.

Badamasi, I. (2014). Distribution of Stomach Food Content of Fish Species Collected from Industrial Waste Water Effluents. A Case Study of Jakara Dam. International Journal of Innovation andTechnology, 5(2): 124-129.

Butu, A.W., Bello, M.I., Atere, P.M. and Emeribe, C.N. (2019). Assessment of Heavy Metals Pollution in the Surface Water from Thomas Dam, Kano State, Nigeria. Nigerian Research Journal of Engineering and Environmental Sciences 4(2): 789-800.

Correia, A. D.; goncalves, R.; Scholze, M.; Ferreira, M. and M. A. Henrigues, (2007). Biochemical and behavioral responses in gill head seabream (Sperus auratus) to phenanthrene. J. Exper. Marine Boil \& Ecology., 347:109-122.

Dane, H and T. Sisman, (2017). A Histopathological Study on the Freshwater fish Species Chub (Squalius cephalus) in the Karasu River, Turkey. Turkish Journal of Zoology, 41(1):1-11.

Dawaki M.U., and Shu'aibu A.U. (2013). Lettuce (Latuca sativa L.) Along The Jakara Valley in Metropolitan Kano, Nigeria: Potentials And Threats. International Conference on Drylands, 232-241.

Farombi, E.O, Adelowo, O.A and Ajimoko, Y.R. (2007). Biomarkers of Oxidative Stress and Heavy Metal Levels as Indicators of Environmental Pollution in African Cat Fish (Clarias gariepinus) from Nigeria Ogun River. International Journal of Environmental Research and Public Health, 4(2):158-165.

Food and Agricultural Organization/ World Health Organization Food Standards CODEX Alimentarius, (2018). Pesticide Residues in Food and Feed-Pesticide index. CODEX Pesticides Home. Available at http:/ / FAO\%20WHO\%20pesticide\%20MRLs.html

Friday, U., Wokoma, O. A. F and Jonah, A. E. 2013). Levels of Bioaccumulation of Some Heavy Metals in Fish (Tilapia zilli) and Their Concentration in Water and Sediment of Owubu Creek, Niger Delta, Nigeria. Resources and Environment, 3(3): 59-64.

Habu M.A., Bawa U., and Musa S.I. (2021). Health Risk Assessment and Heavy Metal Bioaccumulation in Vegetables Irrigated with Waste Water in Kano State, Nigeria. Notulae Scientia Biologicae Journal, 13: 1-8. 
Hosnia, S; Abdel-Mohsien, M and Mahmoud, A, M. (2015) Accumulation of Some Heavy Metals in Oreochromis niloticus from the Nile in Egypt: Potential Hazards to Fish and Consumers. Journal of Environmental Protection, 6(1): 1003-1013.

Ibrahim, S. and Nafi'u, S.A. (2017). Macroinvertebrates as Indicators of Water Quality in Thomas Dam, Dambatta, Kano State, Nigeria. Umar Musa Journal of Microbiological Research, 2(1):1-13.

Ibrahim, S. and Sa'id, H. A. (2010). Heavy Metals Load in Tilapia Species: A Case Study of Jakara River and Kusalla Dam, Kano State, Nigeria. Bayero Journal of Pure and Applied Sciences, 3(1): 87 - 90.

Imam, T.S and Balarabe M.L. (2012). Impact of Physicochemical factors on zooplankton species richness and abundance in Bompai-Jakara catchment basin, Kano state Nigeria. Bayero Journal of Pure and Applied Sciences,5(2): 34-40.

Ishaq, S.E; Rufus, S. A and Annune, P.A. (2011) Bioaccumulation of Heavy Metals in Fish (Tilapia Zilli and Clarias Gariepinus) Organs from River Benue, North-Central Nigeria. Pak. J. Anal. Environ. Chem., 12(1\&2): 25-31.

Jamila T.S., and Sule S.Y. (2020). Assessments of Quality Index of River Getsi Irrigation Water in Kano Metropolis, Nigeria. International Research Journal of Pure and Applied Chemistry, 21: 8-16.

Kutama, R.M; Mohammad, M. A and Mohammad; M.L. (2014).The plankton as Indicators of Water Quality in Kusalla Reservoir: A shallow Man Made Lake. Journal of pharmarcy and Biological Sciences, 9(3):12-15.

Magaji A.S., and Rabiu S. (2020). Birds of Wasai Reservoir, Minjibir , Kano - Nigeria. Science World Journal, 15: 19-25

Mohammed D., Hakim S., Mohamed M. and Andrew R. (2017). Spatio-temporal evolution of the physico-chemical water characteristics of the Sebaou river valley Great Kabylia, Algeria. Journal of Hydrology: Regional Studies 12 (2017) 33-49

Nsofor, C.I., Igwilo, I.O., Ikpeze, O.O., Ikeogu, C.F., Umeoguagu, F.O. and C.J. Okonkwo, 2014. Bioaccumulation of heavy metals in Shellfish Macrobrachium rosenbergi in Niger River at Onitsha, Anambra State, Nigeria. International Journal of Agriculture and Bioscience., 3(1): 38-40.

Oladeji, S. O. (2020). Evaluation of physicochemical parameters in wastewater from Muhammad Ayuba dam in Kazaure, Jigawa state, Nigeria. Archives of Agriculture and Environmental Science, 5(4): 482-488.

Putshaka J. D., Akyengo O., Yakubu A., Adejube A. A. H (2015). Bioaccumulation of Heavy Metals in Fish (Tilapia zilli) and Bullfrog (Pyxicephalus edulis) from River Challawa, Kano State Nigeria. International Journal of Ecological Science and Environmental Engineering, 2(4): 30-34.

Rabiu, H. D., Umar, L. M., Sulaiman, I., Madina, M., and Abubakar, A. I. (2018). Assessment of the Water Quality of Watari Dam, Kano State Using Selected Physicochemical Parameters. International Journal of Advanced Academic Research, 4(5): 62-77.

Reddy, P.B. (2018). Study on the Toxic Effects of Waste Water in Cat Fish (Heteropneutus Fossilis). Life Sciences International Research Journal, 5(2): 165-174.

Samson, E. A., (2015). Heavy metals Bioaccumulation and Histopathological Changes in Auchenoglanis occidentalis fish from Tiga Dam, Nigeria. Journal of Environmental Health Science \& Engineering, 13(67): 2-8.

Shawai, S. A. A., Nahannu, M.S., Abdulkadir, S and Minjibir, S.A. (2018). Evaluation of Physicochemical Parameters and Some Heavy Metals in Water Samples Used For Irrigation Purpose along River Tatsawarki In Tarauni L.G.A, Kano. International Journal of Scientific Research in Chemical Sciences, 5(6):1-4. 
Sulaiman A.U,Dogarai S.B.B.,Kwazo H.A.,Mohammed s., and Bagna E.(2020).Extraaction of Heavy Metal in Tannary Effluent Using Aboundant Agricultural Wastes.International journal of Science for Global Sustainability,: 48-55.

Umma, M., Ibrahim, M., Tasi'u, Y. R., Binta, S. B., Jamila, M. H and Hassan, K. Y. (2014). Effects of anthropogenic factors on the phytoplanktons distribution of Watari Dam, Kano State Standard Research Journal of Agricultural Sciences, 2(8): 136-141.

Usman, L. U. and Adakole, J. A. (2017). Biodiversity Assessment of Some Benthic Macro Invertebrate in Ajiwa Reservoir Katsina State, Nigeria. Umaru Musa Yar'adua University Journal of Microbiology Research. 1 (2): 107-113 